\title{
Washington's Life and Training
}

\author{
By Claude R. Cook
}

The boyhood of George Washington is one of the obscure chapters in his life. His education, his sports, his adventures and his ambitions are the least known about him. For many years a collection of fables and legends and historical fiction grew up to give him the background for the heroic figure he became.

He was born at West Creek plantation, West Moorland county, Virginia, at ten o'clock in the morning of February 22, 1732. (By the old style calendar it was February 11th.) His father was Captain Augustine and his mother was Mary Ball. He was christened the following April in the Episcopal church and it is believed the Reverend Lawrence De Butts baptized him. The infant wore a soft white brocade christening robe lined with rose silk, which is now carefully treasured in the National Museum in Washington, as is also the silver bowl which was used as a font in the baptismal service.

When he was three years old, the family moved to another one of their plantations in what was then Prince William county, which estate afterwards came to be called Mount Vernon, and here they lived until George was seven years old and his education by his father and mother was begun. About this same time, his father decided to move his family to a farm he had purchased on the Rappahannock river opposite Fredericksburg. He made another trip to England and brought back a shipload of convicts. Among them was one William Grove, a man of education, likely a political prisoner, who became the first teacher George had. This man was made sexton of the church at Falmouth, about

- An address delivered before The Service Men's Club, at the Standard Club, 615 High Street, Des Moines, Iowa, February 22, 1955, by Claude R. Cook, Curator of the Iowa State Department of History and Archives. 
two miles from the Washington farm, to which they moved about 1740 .

The Reverend Jonathan Boucher, an English clergyman, who was employed by General Washington as a tutor for his step-son, John Parr Custis, said of Washington, "George like most thereabouts, had no other education than reading, writing and accounts, which he was taught by a convict servant whom his father brought for a schoolmaster."

Despite all the myths, George was a natural, normal lad. He was a strong and vigorous youth. His father taught him to ride his pony and sent him to school in care of a servant until he learned to manage the pony by himself; also impressed upon him the importance of exercise and developed in him a strong love of sports, with a desire to play every game to win-and he loved all games.

His father died when he was eleven years old. A farm of 280 acres was willed to George and it was in his mother's hands until he was of age.

He was sent to live with his half brother; Augustine, at Bridges creek, because the best school available was close by. Augustine had married a wealthy girl and they lived in the comfortable fashion of the prosperous planter. He had a library and thirty horses in his stables; close by were young folks of George's age, so he found the change to Williams school very pleasant.

Here he was a leader in all games and sports of vaulting, running, jumping, pitching sports and throwing the bar; he excelled in horsemanship and it was here that he became interested in surveying. He undoubtedly realized that his education would be limited at best so he applied himself seriously to such studies as were available to him, but despite his remarkable absorption in books, adventure lured him.

There is a tradition that when George was fourteen, his brother Lawrence understanding the boy's dreams of travel and especially of going to sea, secured for him a midshipman's warrant. His mother's reluctant con- 
sent was finally obtained and his luggage was placed aboard the ship of His Majesty's Navy, anchored in the Potomac, when his mother changed her mind and withdrew her consent, so George had to abide by her final decision. Though trained to implicit obedience, it was a bitter disappointment.

\section{Became a SuRveyor}

About the time he was fifteen, he went to live at Mount Vernon with Lawrence, his step-brother. His desire to be a surveyor became his objective, as surveyors were few and their earnings were exceptionally good. George was engaged by Lord Fairfax as an assistant to his instructor, James Glenn, who was a county surveyor, to aid in the survey of the Fairfax holdings in the Shenandoah valley, which consisted of thousands of acres. Lord Fairfax was devoted to the boy and is said to have summed up his estimate of this favorite in a letter to Mrs. Mary Washington in which he said:

Honored Madam: You were so good as to ask what I think of a temporary residence in England for your son, George. It is country for which I myself have no inclination. The gentlemen which you mention are certainly renowned gamblers and rakes, which I would be sorry for your son to be exposed to, even if this means he is admitted to a residence in England. He is strong and hardy and as good a master of a horse as I could desire. His education might have been better, but what he has is accurate and inclines him to much life out of doors. $\mathrm{He}$ is very grave for his age, reserved in his intercourse, not a great talker at any time. His mind appears to me to act slowly, but on the whole, to reach just conclusions and he has an ardent wish to see the right of questions-what my friend, Mr. Addison, was pleased to call, "The Intellectual Conscience."

Method and exactness seem to be natural to George. He is, I suspect, beginning to feel the sap uprising, being in the spring of life, and is getting ready to be the prey of your sex, wherefore may the Lord help him, and deliver him from the nets which those spiders, called WOMEN, will cast for his ruin. I presume him to be truthful, because he is exact. I wish I could say that he governs his temper. He is subject to attacks of anger on provocation, and sometimes without just cause; but as he is a reasonable person, time will cure him of this vice of nature, and in fact he is, in my judgment, a man who will go to school all his life and profit thereby. 
I hope, Madam, you will find pleasure in what I have written, and will rest assured that I will continue to interest myself in his fortunes.

I am honored by your appeal to my judgment, I am, my dear madam, your obedient humble servant; Fairfax."

\section{High Standards Set}

From a paper found in the early writings of Washington, copied from the original with literal exactness and edited with notes by J. M. Toner, 1888, were found the rules of servility which it is assumed he copied from a work by Hawkins, which was in wide use in France and England. There were 110 of these and he had copied them verbatim. Imagination, natural disposition to do everything well and the influence around him which encouraged him toward the high standard of perfection, and his attainment of these standards is shown by more recent surveys in the same territory with modern instruments which show that the lines he helped to mark out when he was a lad of sixteen are decidedly correct.

The hardships he endured as a surveyor in the service of Lord Fairfax prepared him for out-door activity and for future travels of a similar nature. Thus, he was ready when sent upon an important mission by Governor Dimwitty. It also fitted him for the part he was called upon to take when serving under General Braddock and later as commander-in-chief of the Virginia forces. When he officially was given the appointment as public surveyor, he was prepared for it. His only occasion for travel beyond his native shores was when he accompanied his half-brother, Lawrence, to the Barbados, where the latter went in search of health. It was here that he contracted smallpox, which left permanent marks upon him.

$\mathrm{He}$ was commissioned to investigate the erection of French fortresses on the Ohio, which commission he carried out with such success that he was appointed lieutenant colonel, in command of troops sent by Virginia to aid in building forts in defense of British possessions against the hostilities of the French, which 
ended disastrously and in retreat and surrender at Fort Necessity.

When Colonel Fry died, the chief command of the troops fell upon Washington. Independent companies arrived at the fort and still others were enroute. When Washington was apprised of the approach of Captain MacKay, he began to wonder whether MacKay was to be under his command or independent. He had learned that officers commissioned by the Crown sought precedence over those commissioned by Colonial governors.

The question of rank came up again the next year when he had resigned his commission, returned to agricultural pursuits and was invited by General Braddock to join the general's official family as a volunteer. Braddock had learned that knowledge of Indian warfare, which Washington had previously gained, proved invaluable and Washington was led to expect a royal commission. He steadily refused to serve under any commander whose titular dignity was inferior to his own and he was upheld in this by his companions in arms. But the question of rank arose again and it could not be settled, so Washington asked permission to go to Boston to get Governor Shirley, Commander of the King's Forces in America, to decide the matter. Shirley did not have the power to grant commissions in the standing army, but he gave an order that Washington should command when he and Captain MacKay should join forces.

\section{Married and ENTERed Official LifE}

When this campaign closed, he was married to Martha Dandridge Custis and took his seat in the Virginia House of Burgesses, to which he had been elected while he was absent on military duty. The delightful trip from Williarnsburg to Mount Vernon, which had been placed in readiness for him, was a very happy journey. There, for a period of sixteen years, he followed peaceful pursuits, punctuated by occasional short journeys.

George Washington was a thorough-going American 
with the ingenuity of the American. He was very circumspect in his dress and always wore clothes befitting the occasion. But he never hesitated to meet emergencies by adopting any methods which were apparently necessary. On one occasion he urged the British commander to allow him and his men to adopt Indian dress, adding, "Tis an unbecoming dress for an officer, I confess, but convenience rather than shew, I think should be consulted." The general gave him leave and it was done.

But after the separation of the Colonies from the mother country, he became an ardent advocate of having his garments made in America, both as to material and tailoring. However, he was not always able to obtain the materials for such garments as must be included in the wardrobe of the president of the United States, so from necessity rather than choice, London merchants were again patronized, but he had definite specifications about what he wanted and what he did not want.

A cynic once said that we go through life with only one true friend, and that person is his or her mother. That certainly was not true of George Washington, for he did possess his mother's deep affection, but he also had the devotion of the majority of those who crossed his pathway. As he ascended the pinnacle of fame, his old friends, even those of boyhood days, stood shoulder to shoulder by his side.

Very few lives have been laid bare in the same manner as that of George Washington and stood the test of time as well as of critics. A few historical facts of his boyhood have been distorted, his private life has been discussed from every angle, and his official life, which rightfully belongs to the public, stands out in bold relief as a shining example to the world. His friendship and intimacies with the Fairfaxes and Carlisles ended only with death.

He probably had more honors conferred upon him than any other man in American history until the ad- 
vent or the near closing period of Herbert Hoover's important impact upon the United States and upon the world. For it is extremely doubtful if any living man. in the United States or in the world has had as many honors conferred upon him as has Herbert Hoover.

George Washington was extremely devoted to his wife - and her sons and immediately adopted them and bestowed upon them the same affection he would have, had they been his own. In fact, he could not have been more interested in their welfare had they been his own children. Martha Custis was the widow of a very wealthy man and was an extremely gracious, patient and understanding woman. She was devoted to Washington for the remainder of his life.

Of his brothers and step-brothers, there was only one for whom he did not hold very high regard and that was his brother Samuel, of whom he said, "He constantly kept himself in debt," which to Washington was unpardonable. In addition to his indebtedness difficulties, Samuel was also a very hard and devoted addict of liquor. This, of course, George did not countenance and for that reason, it was the only apparent deflection in his admiration for the members of his family.

Devoted to His Mother

His mother, Mary Ball, was one of the remarkable women of any age. She instilled in him the high standards to which he later attained and his devotion to her as well as her devotion to him never seems at any time to have had abatement in any degree. In fact, all during his activities before his marriage and whenever opportunity presented, during his military campaigns or upon whatever mission he had been sent, he was constantly keeping her in mind and writing her letters from a devoted son and upon every occasion returned home to visit her.

His activities as a general and his conduct of the Revolutionary war against the British must be left for another paper. It shall be considered enough to be said here, and historians are in agreement on this, that he 
was the only man in the colonies at the time who could have gotten the forces of the colonies together, held them together and achieved a final victory. It has been said over and over again that no other man of his time could have accomplished this important beginning of a new nation. It has been said of him, as he has been called a great general, and he was a great general, that "he never won a battle, but never lost a campaign." Of course, the tide was turned when the French came to the rescue of Washington and the Revolutionary forces. General Lafayette came to his assistance and became his very great friend. This was a friendship that continued long after the Revolutionary war.

An interesting side-light on this friendship is indicated by the presentation of a Masonic lodge apron that Mrs. Lafayette made for him by hand and presented to him. It was a beautiful work of handcraft and George Washington wore this apron when he laid the cornerstone for the capitol building in Washington.

On another occasion Lafayette sent him a number of hound dogs, quite a number in fact, and these dogs were used on the plantation. But one of them, whose name was Vulcan, must have had some rather easy access to the home or at least to the kitchen. For on one occasion, when guests had been invited for a dinner and Martha Washington had on her menu a Virginia ham and the ham had been nicely prepared by the cook in charge, old Vulcan somehow got into the kitchen and when discovered, the Virginia ham had become a part of old Vulcan's development. There is no note as to how old Vulcan fared after having consumed a ham, but in these modern days of emphasis upon pets and dogs, it is well known that a very poor thing to feed a dog is ham or a ham bone. It is altogether likely that in those days the hams were not so highly treated with salt which seems to be the factor that provides a deterent in these modern days and can do things to a dog's digestion that most other foods cannot, and perhaps the old dog got through the ordeal all right. 
To be indicated from the above, George Washington was a strong member of the Masonic lodge. He served as Worshipful Master of the Masonic lodge at Alexandria and was also Grand Master of the Masonic lodge of Virginia, and in this capacity served the fraternity in many different ways. Through the years Masonic lodges throughout the country have observed his birthday with adequate ceremonies. There is an interesting story in connection with the Boston Tea Party that involves members of the Masonic fraternity. It is a well known part of authenticated history that in Boston there was the old Green Dragon tavern, but historians have not often related the fact, that above the old Green Dragon tavern was the Masonic lodge room; that here the Masons met in regular and perhaps called meetings. Of course, this was about the time and period of the great tea tax which Britain had imposed upon the colonies, which might well be viewed in modern times as one of the first impositions of the sales tax. But in any event, it was distinctly unpopular with the colonists and it was their decision that they would drink no British tea as long as the three per cent tax was imposed. But Britain expecting to enforce not only the delivery but the imposition of the tax, sent the three ships loaded with tea into the Boston harbor.

Time after time, in this Masonic lodge over the Green Dragon tavern, discussions arose as to what would be done when the ships arrived and what disposition should be made of the tea. But it apparently had been well decided, perhaps as perfectly as the famous ride of Paul Revere. For the Masons came together in their meeting when the ships laden with tea were lying in Boston harbor. The meeting was called to order and the Masons, of course, appearing with Masonic white aprons were in attendance. There isn't any record upon the lodge books, but it is known that the meeting was closed, that the Masons doffed their aprons and donned the garb of Mohawk Indians. John Hancock, who was the secretary of the lodge, signed his name the full 
length of the page so, as he put it, "King George could read it without his spectacles." These Masons suddenly transformed into Mohawk Indians went down to the harbor and dumped the tea into the water, and thereby set up perhaps one of the greatest tempests that was ever stirred up in any teapot in the whole world.

WashINGTON'S FaREWELL ADDRESS

It has been observed in previous paragraphs that Washington was a thorough-going American; that he had no desire to be thought of as anything else; moreover, did not wish to be involved or aligned with anything which was not American. It has been said recently that he did not use the term, "no entangling alliances," but it is altogether likely that this was an epitome of some things which he said in the closing paragraphs of his farewell address, after having served as president. Here I insert quotations from that Farewell Address. He had been stressing the advantages of the new nation and its peculiar opportunities and speaking against the idea which still prevailed among. many that we should follow the monarchial forms of government of the old world, or copy this or copy that. I have foregone the privilege of quoting much of it, but these quotations follow along after that and this is what he said in that connection:

Why forego the advantages of so peculiar a situation; why quit our own to stand upon foreign soil; why, by interweaving our destiny with that of any part of Europe, entangle our peace and prosperity in the toils of a European ambition, rivalship, interest, humor or caprice? 'Tis our true policy to steer clear of permanent alliances of any portion of the foreign world; so far, I mean, as we are now at liberty to do it.

This reference is to such existing agreements as had been entered into with foreign countries. Then he goes on to emphasize that these agreements should be carried out by saying, "Public honesty and private honesty are on the same basis," and he also says that "honesty is always the best policy." "Let the engagements be observed in their genuine sense, but in my opinion it would be unwise to extend them." 
It is interesting to observe that when the Colonies came together under what was thought of then as a Confederation of the Colonies, there was considerable question as to whether they would survive. Certainly Britain did not think so and Carlisle gave the new Republic fifty years. Washington himself had some doubts about whether the differences could be composed and held so as to keep the Union strong. But as the years moved along, he adhered to the policy and the principle that the Union could and would stand, but that it would always depend upon the people of the United States to see that it did. Of the constitution, when he had occasion to make reference to it, which he frequently did, always with reverent awe, he was continually emphasizing the fact that it was not a wholly perfect instrument, but that the process of amendment insured its integrity and its strength and its survival. This he never failed to see and impress upon those 'round about him.

I think that the American way of life, the liberty which was founded upon such principles as were enunciated by George Washington, has rather a close relationship with the Christian religion. For with all the assaults that have been made both upon the constitution and the American way of living and the Christian religion, they have both survived. They had to be right, they had to be true and they had to meet the needs which were imposed upon them in order to withstand such assaults. In my judgment, this is one of the most convincing presentations which can be made of their rightness, their integrity, their truth and their ability to serve mankind.

\section{Washington Taken Over}

It is interesting in this connection to remember that George Washington as the first president of the United States did not take the country over. The country took him over. There were no black shirts, no brown shirted fantastically organized pressure mobs to take over the government of the United States. George Wash- 
ington was taken over by the people, and based upon his accomplishments and the fundamentals embedded in the constitution, the nation has grown to the enormous importance it has in the world.

Let us look again at his emphasis against entanglements with foreign countries. I am of the firm conviction that if we had adhered through the years to the principles he enunciated upon this subject, this nation would be in a far different and a far better situation in the world than it is today. I am not one of those who wants to go back to or bring back the old days. I lived in some of the old days and my father lived in some old days. My grandfather, who was one of the first three white men to settle in Platte township of Union county of this state, lived in what is known as the "good old days." I am not for bringing them back, but I am saying that we fought two wars, World War I and World War II on foreign soil on the theory that it was much better to fight America's battles on foreign soil than it was to have to fight them on our own. But you cannot keep on throwing your garbage and your refuse over into your neighbor's yard without ultimately his throwing them back along with some of his own. In other words, he will eventually retaliate.

We have gone into two wars, three if you want to count Korea, on the theory that we could thus avoid a war on our own soil. Only the other day President Eisenhower intimated that there may have been a miscalculation in both World War I and World War II, and even hinted that there may have been such a thing in the Korean case. General McArthur in his famous birthday celebration address in Los Angeles, only recently set forth the fact which has been known since the time of Washington because he enunciated some of the same principles, that no country wins in a war and that everybody loses.

What is the conclusion of this sentiment? Simply this, now that we have dumped our bombs and sent our soldiers and our navy and our air force to foreign soil, 
we face the prospect of having the next war upon our own shores and upon our own soil. I submit to you that had the principles of Washington been observed, not because they are old, but because they are fundamental, and a fundamental principle is never outgrown, we might have avoided many pending problems.

Now, I would like to add something in connection with the Constitutional Convention, that was held in Philadelphia. It convened in May and finally concluded on the 17th day of September. This convention, one of the most important which has ever been held within the history of mankind and was the birthplace of what was at the time called; "One of the Great Experiments in Government," was not an easy convention. It was a trying and troublesome assembly. Travel conditions were at their very worst. It took George Washington two weeks to travel from Mount Vernon to Philadelphia. I have done it myself in an automobile in four hours and today it could be done by jet propelled airplanes in almost no time at all. In fact, you would hardly be off the ground in a plane operated by jet propulsion in either city before you would be over the other one. Some of the delegates never did get there. Some of them did not arrive until the convention was almost over. Some of those who were there became so angry, they went home.

It was a convention of great soul-searching debate and men's souls were tried. But it finally came to its conclusion, finally drawn so that it met the approval of those who signed it and the majority of those who were present. Of course, the thing that made it possible at all was its susceptibility to amendments. Without this provision, it might never have been conceived.

On the final day, the 17th day of September, when the signing time came, the delegates marched down to the table at the front of the hall to affix their signatures. Benjamin Franklin, one of the great delegates had an aisle seat. He marched down, affixed his signature and before he was seated and while the last members were 
signing the constitution, Dr. Franklin looking toward the president's chair at the back of which a rising sun happened to be carved, and the design was not too clear and not too easy to establish whether it was the intention of the artist to present a rising or a setting sun, Dr. Franklin said to those members near him, "I have often and often in the course of this session, and the vicissitudes of my hopes and fears as to its issue, looked at that painting behind the president, without being able to tell whether it was a rising or setting sun; but now at length $I$ have the happiness to know that it is a rising and not a setting sun."

My fervent wish and hope is that we will always see to it that it is a rising and not a setting sun. That this nation is not in the sundown period of its experiece, but that it is five o'clock in the morning for the United States of America.

\section{Life's Miracle}

By Paula Bishop

The great miracle

Of life

Is renewal.

There is death,

But there is birth, too.

There is winter,

But always after it-

Spring!

There is disappointment,

But also hope!

We don't understand it.

We just accept it. 
Copyright of Annals of Iowa is the property of State of Iowa, by \& through the State Historical Society of Iowa and its content may not be copied or emailed to multiple sites or posted to a listserv without the copyright holder's express written permission. However, users may print, download, or email articles for individual use. 